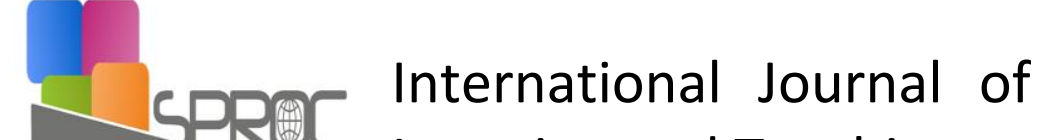

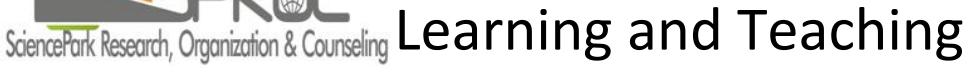

Volume 09, Issue 01, (2017) 349-356

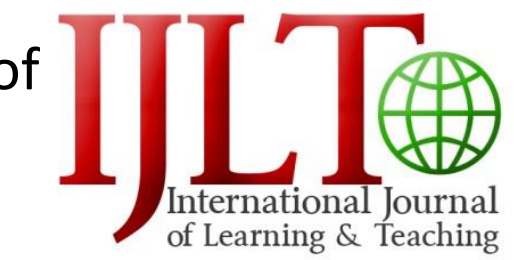

www.ij-It.eu

\title{
Adaptation of two years old children in Czech preschool education
}

Lucie Gruzova*, Department of primary of education, Faculty of education, Masaryk University, 6230, Poříčí 31 Brno, Czech Republic

Zora Syslova, Department of primary of education, Faculty of education, Masaryk University, 62300, Poříčí 3, Brno, Czech Republic

\section{Suggested Citation:}

Gruzova, L. \& Syslova, Z. (2017). Adaptation of two years old children in Czech preschool education. International Journal of Learning and Teaching. 9(1), 349-356

Received August 14, 2016; revised November 6, 2016; accepted January 9, 2017.

Selection and peer review under responsibility of Prof. Dr. Hafize Keser, Ankara University, Ankara, Turkey. (C)2016 SciencePark Research, Organization \& Counseling. All rights reserved

\begin{abstract}
The article presents current topic in Czech preschool education. Czech preschool education has been dealing with placing of two years old children to kindergartens. There is economic and social pressure for receiving two years old children into kindergartens, however, contemporary pre-primary education is for children from three until six or seven years old in the Czech Republic. The network of facilities caring and education for children a up to three years of age are missing in the Czech Republic. The article presents results of qualitative research focusing on adaptation of two years old children from teachers' perspective. The methods of questionnaire and observation were used. The research brings findings on kindergarten teachers working with two years old children in Czech kindergartens and how children develop in current conditions.
\end{abstract}

Keywords: pre-primary education, pedagogical quality, two years old children, teachers' professional competences, observation.

*ADDRESS FOR CORRESPONDENCE: Lucie Gruzova, Department of primary of education, Faculty of education, Masaryk University, 6230, Poříči 31 Brno, Czech Republic. E-mail address: luciegruzova@seznam.cz 


\section{Introduction}

The question of Early childhood education and care (ECEC) became very important issue for European family policy. One of the main goals of European family policy is to ensure a harmonious balance between professional life and family life. The economic, political and social processes of twentieth century have changed European everyday live, have shaped the family, have brought opportunities to work, and have had an influence on the birth rate. Research say (OMEP, 2013) that investment in early childhood development is one of the most effective instruments used to accelerate and achieve the sustainable and secure future that we want for all children (especially children from low social status family).

Education and care for children up to three years of age in many European countries are considered particularly from an economic standpoint, since it allows both parents to work. Previously it worked various devices such as nurseries or shelters, and it was systematically canceled and to this day there are again a lot of settings with these functions. However, there has been an increasing interest in the education of the youngest children with an emphasis on the emotional, social and physical development in the recent years. (EACEA, 2009) The quality of education plays important role.

The Czech Republic was the state, which had integrated curriculum "Program for educational work for nurseries and kindergartens" in the past and ensured $30 \%$ of children of age from zero to three years are placed in public education. The political, social and economic changes (1989) caused the blanket cancellation of nurseries thus the challenges brought by the EU (harmonization of family and professional life) puts the Czech Republic into problematic situation. The situation is partly solved by private organizations and by trying to (parentsTJET ETBETJ3 of svons publi 
candidates and the children in them are not isolated cases of non-compliance capacity (Kucharova \& Svobodova, 2006).

\section{Theoretical framework}

Early childhood development is very important and it is influenced by characteristics of the child, family, and the broader social environment, for example kindergarten. Physical health, cognition, language, and social and emotional development underpin school readiness. Publicly funded comprehensive early childhood development programs are a community resource that promotes the well-being of young children (Eurydice, 2000). The main question is how important influence comprehensive early education has? Belsky, Vandell, Burchinal, Clarke-Stewart, McCartney, K and Owen (2007) state that for the child development is more important that where the family comes from, that is, whether family is economically viable, whether parents act as partners, if the mother is not oppressed and whether is her parenting receptive to the needs of the child. These things tell us more about life opportunities than child's experiences with child care. In fact, it turns out that the effects of institutionalization are rather medium if not small.

Early education definition speaks about a model of education and care with main aim on physical and psychical and cognitive and social development. (Eurydice, 2000) There are two approaches in public education in Europe (OECD, 2012): integrated model; it means one structure for every child in pre-school age (0-5/6), or age divided model.

Czech pre-primary system is age divided. Parents take care about children zero-to-three years old or there is small opportunity for working parents to use public nurseries or private facilities. Children three-to-six or seven have a state guaranteed place in a kindergarten. The net of kindergartens is formed mainly by public kindergartens under ministry, regions and municipalities.

In the Czech Republic is currently a small number of other childcare services for preschool children than crèches for children under three years of age and kindergarten for children up to six years. Meanwhile we prevail in our care for children zero to three years of age within the family. However, the current economic and political conditions push parents to return to work sooner. Therefore there is a need for other childcare services for children under three years of age. We need to look up to Austria, where the public kindergartens coexist with number of private kindergartens but also family groups, children's groups, daily parents (usually daily mothers) mobile grandmothers and grandfathers to borrow (MPSV, 2012).

Recent British research in the field of formal early education say ${ }_{2}$ that children of parents who work full-time have better cognitive outcomes when they go to the city than when they are in the care of relatives (Layout, 2005). A study of 2003 brings the knowledge that children attending private child care centers are protected from negative impacts of development. The research also shows that children attending nurseries are in cognitive development beyond children being at home with their parents.

It was also examined behavior of the youth who attended high-quality facilities for early education. It has been found to have better academic results and a higher standard of living than their peers (Layout, 2005). Researches speaking against Early institutional education show (Layout 2005) that children attending two years of any facility of early care and are guarded by relatives, are in development behind children spending day with his/her mother.

US Institute for Child Health and Development (Layout, 2005) shows that children who have spent most of their first five years in the early care facilities, are less popular among peers and are more aggressive. Project UK Department of Education and Skills (2003, 2005 in Layout, 2005) found that children who attended day care centers for early education most of the day exhibit antisocial behavior at the entrance to the school.

The question of placing two years old children to kindergarten is wider. Teachers have the negative opinion of the admission of children under three years of age in the current kindergarten, however they know there is the need to provide care for children in this age category. It is necessary to cooperate in creating the conditions for ensuring quality care for children younger than three 
years with the Ministry of Education. We are looking at creating a heterogeneous group of children from 2 to 6 (7) years in the kindergarten very positively. We recognize that the demographic, economic and social situation in the country requires creating wider group of pre-primary education. But it is necessary to create suitable conditions. In the front row to create training for preschool teachers to develop the concept of training program for this age group and subsequently adapt to the specific conditions in kindergartens (Gruzova, 2014). Headmasters usually agree to reduce the age limit for recruitment of children into kindergarten from three to two years. Every third kindergarten children younger than three years is accepted. The problems are these children are officially accepted, but realistically, these children ( $40 \%$ of cases) board until they reach 3 years of age. The main reason is that up to the individual cases of children under three years of age require intensive care. Kindergarten emphasizes the educational function (MPSV, 2012).

\section{Methodology}

The data used in this paper come from qualitative study of kindergarten teachers. The main research question was "What opinion and what experience have kindergarten teachers for working with two years old children?" This main question was investigated in two ways. The first way conducts the study of teachers' working and answers the main question dividing into two parts: (1) what is teachers' thinking of problem of the two years old child in preschool education (2) what professional competences does teacher use with the two years old child. Second ways conducts the study of differences of teachers' work with two years old children and describe working process and what challenges are arisen for teacher?

The qualitative study was designed into two parts. In the first part kindergarten teacher were asked to answer for questionnaire with five open questions as deeply as it is possible. We asked forty five teachers from seven parts of Czech Republic by email. Teachers attended courses for kindergarten teachers financed by EU. 18\% (7) had experience with teaching two years old children, each participant wrote one side of text about this topic. Teachers' answers were analysed by grounded theory. The second part of research was observation of teacher works with two years old children. The data was collected by bachelor student Kateřina Kodetová (2015). Observation was done in private nurseries during day activities from eight o'clock until twelve clock and it was written into prepared table. The observation was passed one time. The dates were analysed and described teacher's work with two years old children.

\section{Findings}

The first part of research brought findings about teachers' thinking about topic two years old children in preschool education. From point of general pedagogy teachers' answers are covered whole important pedagogical spectrum. Teachers spoke about needs of systematic changes, about situation in classroom, about state conditions, about prepare teacher education. Teacher A said: „Two year old child requires constant supervision, care, attention. One teacher has no time for the entire class!" Teacher $\mathrm{C}$ said: "Two years old children are experiencing a period of negativity, they do not understand the need to conform to the group, still do not understand the rules, and if it is a regular kindergarten class, which is usually implemented by 28 children, have created favorable conditions. The needs of this small child are not respected, then. There is no time to practice regular habits - hygiene, grooming, eating. The disadvantage of including two year old child is mostly unsatisfying their needs." Teacher F mentioned: "In amount of 28 children it is a lot for teacher. And they do not have practice." Teacher E said: "Given that we have so far only experiences with two years old children who reached the age of three during autumn. These children were independent and in one class there were no more than two and approached them more individually, but we work with them more or less as a three year old child. The first part of research brought these findings, thus, analyses of teachers' answers showed that the most important areas, what should be solved, are divided into three categories: 1) child, 2) environment and 3) program (table 1). 
Fig. 1 The three most important components of teaching process with two years old children

\section{Child 's immaturity}

1)Physical/mental fatigue

2)Social and emotional unripeness

3)Different play demands

4)Needs of individual care

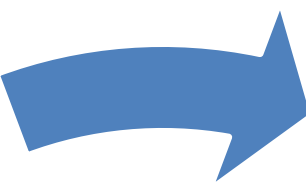

\section{Environment condition}

1)Low personal arranging

2)Missing safety play elements for two years old children
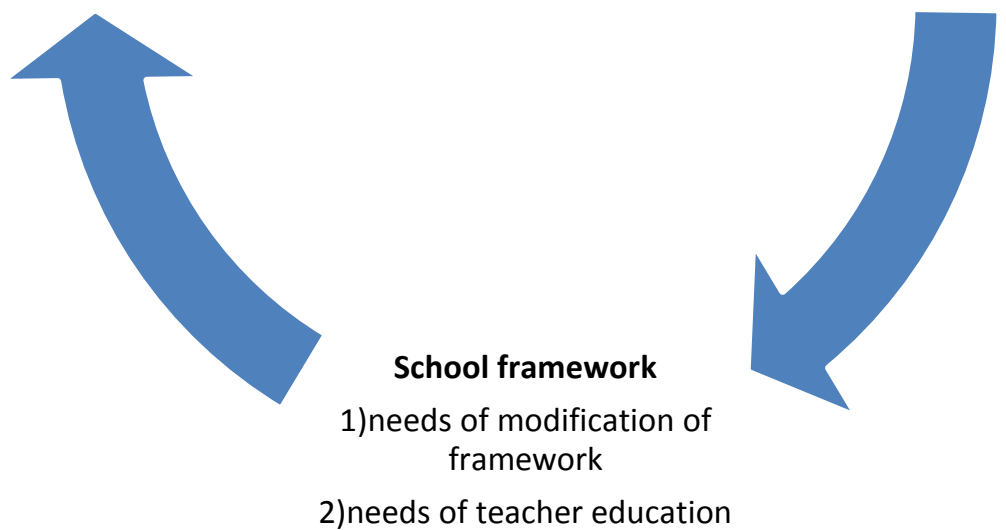

2)needs of teacher education

The first category covers two years old child's individuality as immaturity or child awareness, it is connected with quick physical and mental fatigue; social and emotional unripeness (time of negativism and defiance), children are more depended on family; children have different play demands, thus, they need to change play more frequently; two years old children need more individual care and help with hygiene, eating ect. For teacher it means to work with time, teacher needs more time for individual work and how to educate, when child is not ready to pay attention.

The second category is connected with child immaturity also with psychological, biological and emotion development but in light of condition of Czech education (for example personal condition in class - one teacher for twenty eight children). The routine of the day does not respect the needs of two years old children.

Other important category related to educational process, there is absence of framework for children younger than three years old in the Czech Republic and process of individualization and respectful communication has begun few years before. There is need of modification of university studies or to bring systematical solution.

Positive experience presented teacher E. The framework should be simple, and important parts are hygiene, self care, communication. For everything they need more time than older children. Very interesting were teacher suggested solutions. Teacher D suggested: "Not to include two years old children in collective ordinary kindergarten, expand the network of nurseries or similar facilities where the children are in small groups, but the most ideal is to leave the child in the family under the age of three years." Other solution is from Teacher A to arrange special classes for smaller children with more teachers or assistants and with lower capacity. Teacher B suggested similar solution: „I see the prospect of setting up special classes for small children with fewer registered children and larger 
number of adults - a teacher and assistant. When we speak about two years old child in preschool education we should concentrate to good knowledge about child, diagnostic process, and prepared environment. All of these component are connected with preparing teacher education and national program, where should be important standards define which is missing.

At first we should mentioned what means competences of kindergarten teacher. Professional competences are characterized as complex basis to successful accomplishing profession, what comprehend knowledge, facilities, attitudes, values and personal characteristics. Vašutová (2004) as the only one researcher who gives specific skills directly related to the profession of kindergarten teacher. The starting point for competences was a multi-layer model, the four pillars of the Delors (in Vašutová, 2004) - learning to know, learning to act, learning to live together, learning to be. She targets pillars with assigned function of school - skills, socialization, integration and personalization. It then defines the competencies: 1 . Specific subject competence: The teacher has mastered the systematic knowledge in the field of pre-school education and its related sciences in scope and depth appropriate to the needs of kindergarten; 2 . Didactic and psycho- didactic competence: The teacher controls the strategy of education and learning in a theoretical and practical level, combined with deep knowledge of their psychological, social and causal aspects; 3. Teaching competence: The teacher controls the processes and conditions of education in theoretical and practical knowledge combined with deep psychological, social and multicultural aspects; 4 . Diagnostic and interventional competence: The teacher is able to use the funds education diagnostics in educational activities based on knowledge of individual conditions of children and their developmental peculiarities able to diagnose social relations in the class; 5 . Social, psychosocial and communication competence: The teacher is able to participate in co-creating a favorable climate in the classroom based on knowledge of social relationships of children and co-workers; controls the means of socialization of children; 6 . Management and normative competence; 7. Competence of professional and personal cultivators: The teacher controls a broad range of general knowledge on the general outlook in many areas of life, which can appropriately be transmitted to children; They can act as a representative of a profession based on the adoption of principles of professional ethics of teachers.

Second part of research was observation in class of second way of solution. In a homogeneous class of mostly two-years old children, accounted one teacher for six or seven children. The daily program is calculated with sufficient time for self activity (dressing, hygiene, eating). Class is composed of two relatively small rooms, furniture and sanitary facilities are adapted to growth of children. All items can be due to the homogeneity of the age group accessible to children, but there is no space glutted stimuli. Less space in the classroom is compensated by the size of the garden, where the doors lead from the hallway to next class. While staying at the garden children have easy access to sanitary facilities, and also to the locker room (Kodetová, 2015). The observation lasted four hours and it was focused on teacher, her planning, communication competence, diagnostic competence ect. Teacher was working with two years old children, there has been on different requirements than working in the classroom with children older than three years, which are named by Vašutová. The differences are most evident in the promotion of mutual communication of children in planning activities, daily routine and activities adapting the age of the children and helping with self-care activities. These different aspects of the work of teachers are clearly recorded in fig.2. 
Fig. 2. Main competences of teacher working with two years old children

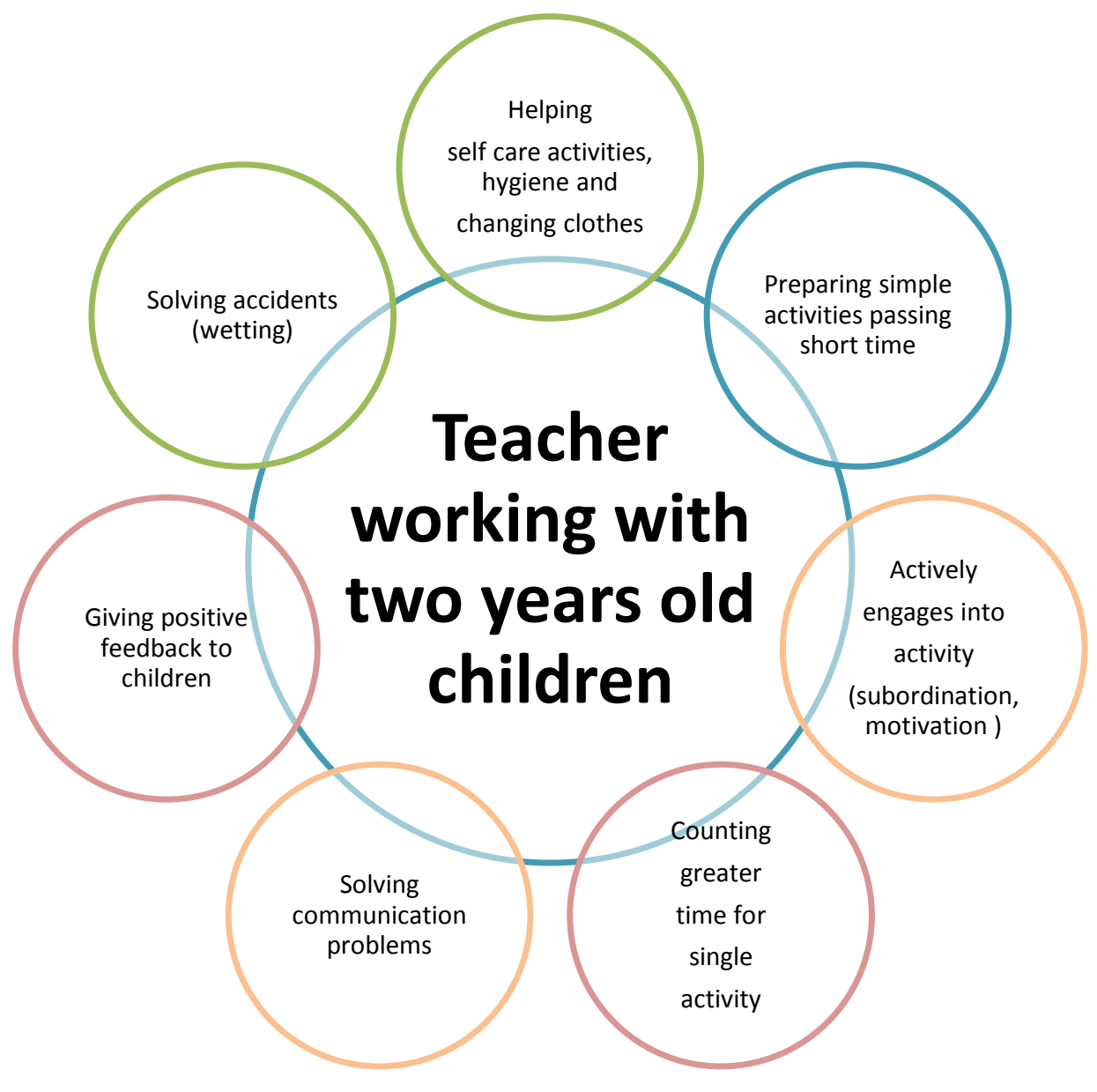

Social, psychosocial and communication competence

Management and normative competence

Diagnostic and interventional competence

Teaching competence

In Fig. 2 we can see that mainly important competences are management and normative competence; social, psychosocial and communication competence; diagnostic and interventional competence and teaching competence. Of course in educational process teacher uses other competences as well, thus, in observing class there were used mainly these four competences.

\section{Conclusion}

The research shows that education policy, conditions of kindergartens and prepare teacher education are not going in one direction in Czech Republic. Kindergarten teacher who is working with two years old children need different competences than teacher who is working with three years old children. Although many two years old children currently attend kindergartens and other institutions providing child care visits, Czech teachers are not ready for this phenomenon. Experts agree on view that the two years old children can learn in kindergarten, however, this must conform to conditions. 
Even in history we find many examples where institutional education for two years old children was good quality.

While Teacher who works with three years old children could offer more difficult activities, support independence in self care activities, plan more activities, teacher who works with two years old children full utilizes three competences-communicative competence because of motivation of children, giving feedback, helping with solving problems between children; management competence because of awkwardness of children; planning competence because of different needs and demands of children. In observing time there was no space for diagnostic competence, which is also important. Teacher working with two years old children should be prepared especially in these three competences: communicative competence, management competence, planning competence.

There is similarity between these conclusions and current political educational situation in the Czech Republic. Despite the Czech government being officially engaged to increasing attention to early education in the Czech Republic, a comprehensive system of education and care for children from 0-6 years of age is one of the most problematical. Care for children up to two years is the responsibility of the Ministry of social work and the education of children from three years of age is the responsibility of the Ministry of Education. There are two ways how to solve this problem. At first divided education model would be continuing, thus, there would be nurseries and kindergarten. At second way integrated model would be implemented, thus in kindergarten would be classes for younger children. Therefore it should be a responsibility of one ministry.

In the Czech Republic there is a lack of clear philosophy and holistic approach to the care and education of children under 6 years of age. In terms of ensuring a holistic development of children and continuity in education solution would be to merge the entire age range of early care and education for children from 0-6 years in one integrated system as it was in the past and can be observed in many other OECD countries as well. There is opportunity to suggest family life and children development. There is also other side of teacher education, because now days there does not exist debate about how to learn and work with two years old children and younger children.

\section{References}

Belsky, J., Vandell, D. L., Burchinal, M., Clarke-Stewart, K. A., McCartney, K., \& Owen, M. T. (2007). Are there long-term effects of early child care? Child development, 78(2), 681-701.

Eacea.(2009) Vzdeavani a pece $v$ ranem detstvi v Evrope: překonávání sociálních a kulturních nerovností. Brusel: Eurydice.

Kodetová, K. (2015) Two years old children in kindergartens. Bachelor thesis, Masarykova univerzita, Pedagogická fakulta.

Layout. (2005) Avon Longitudinal Study of Parents and Children (ALSPAC), University of Bristol, UK.

MPSV. (2012) Analysis of the conditions and the possibility of inclusion of children aged two to nursery schools and the additional solutions extension of care for children under three years of age.

OECD. (2012) Quality Matters in Early Childhood Education and Care: Czech Republic, on line.

OMEP. (2013) Istanbul Declaration. 